\title{
Use of an Expanded Polytetrafluoroethylene (ePTFE) Dura Substitute in Glioma Surgeries: A Technical Note
}

\section{Uso do substituto dural politetrafluoroetileno expandido (ePTFE) em cirurgias de gliomas: Uma nota técnica}

\author{
José Marcus Rotta ${ }^{1}$ Rodolfo Casimiro Reis ${ }^{2}$ Ana Lucia Mello de Carvalho ${ }^{2}$ \\ Matheus Fernandes de Oliveira ${ }^{2}$ \\ ${ }^{1}$ Department of Neurosurgery, Hospital do Servidor Público Estadual \\ de São Paulo, São Paulo, SP, Brazil \\ 2 Department of Neurosurgery, Neuro-oncology Section, Hospital do \\ Servidor Público Estadual de São Paulo, São Paulo,SP, Brazil \\ Address for correspondence José Marcus Rotta, MD, Department of \\ Neurosurgery, Hospital do Servidor Público Estadual de São Paulo, \\ Alameda Santos, 122 conj 101, São Paulo, SP, 01418-000, Brazil \\ (e-mail: josemarcusrotta@gmail.com).
}

Arq Bras Neurocir 2019;38:236-238.

\begin{abstract}
Introduction Reoperations are a common scenario among glioma patients. There is crescent evidence of its benefit in low- and high-grade gliomas. Here we discuss our experience with inert expanded polytetrafluoroethylene (ePTFE) dura substitute in glioma surgeries.

Technical note We generally put the ePTFE dura substitute below the dura of the

Keywords

- reoperation

- glioma

- dura substitute

- surgical complication

Resumo
Palavras-chave
- reoperação
- glioma
- substituto dural
- complicação cirúrgica
patient, even if it is intact. This membrane should be sutured in place using a tensionfree technique, with 4-0 polypropylene. Expanded polytetrafluoroethylene minimizes tissue attachment and fibrosis when performing reoperation in glioma patients.

Discussion Since the literature has shown benefits in survival with reoperation in glioma patients, the use of ePTFE dura substitute can improve surgical time and minimize complications in a second surgery.

Introdução Reoperações são comuns entre pacientes portadores de glioma, com crescente evidenência de seu benefício em casos de baixo e alto graus. Aqui discutimos nossa experiência com o substituto dural politetrafluoroetileno expandido (ePTFE) em cirurgias de glioma.

Nota técnica Geralmente colocamos o substituto dural ePTFE abaixo da dura-máter do paciente, mesmo quando intacta. Essa membrana deve ser suturadasem tensão com fio prolene 4.0. ePTFE minimiza aderência tecidual e fibrose, facilitando as reoperações em pacientes com glioma.
\end{abstract}

๑José Marcus Rotta’s ORCID is https://orcid.org/0000-0003-3452-4104.

received

February 14, 2019

accepted

April 8, 2019
DOI https://doi.org/

10.1055/s-0039-1688835. ISSN 0103-5355.
Copyright (e 2019 by Thieme Revinter

Publicações Ltda, Rio de Janeiro, Brazil
License terms

(c) $(1) \$$ 


\section{Introduction}

Reoperations for recurrent low-grade gliomas (LGG) should be the standard of care. ${ }^{1}$ Concerning high-grade gliomas (HGG), reoperation remains controversial, given the limited life expectancy and the aggressive/recurrent nature of these tumors, but there is crescent evidence of benefits with this treatment strategy. ${ }^{2}$ Recent studies have shown that a second operation improves survival in patients with glioblastoma multiforme (GBM), with surgical complication rates similar to single-surgery patients. $^{3,4}$

Reopening the dura mater and releasing it from the cerebral cortex in a glioma reoperation can be difficult and increase the surgical time; besides, it may cause cortical injury. Due to the important role of reoperation in glioma patients, here we discuss our experience with inert expanded polytetrafluoroethylene (ePTFE) dura substitute in glioma surgeries to minimize the difficulties of reoperation.

\section{Technical Note}

When planning surgery in patients with suspected gliomas in magnetic resonance imaging (MRI) studies, we routinely use an ePTFE dura substitute. After lesion resection and hemostasis of the tumor bed, we put the membrane below the dura of the patient, even if it was intact, as shown in -Fig. 1. The ePTFE dura substitute should be sutured in place using a tension-free technique. This can be achieved by appropriately sizing the membrane to slightly overlap the dural defect and putting minimal tension on the sutures (-Fig. 2). This may avoid unnecessary needle punctures in the material. The substitute is compatible with any nonabsorbable suture with a noncutting needle, such as a taper or piercing point. We used 4-0 polypropylene in all of the cases.

As shown in -Figs. 3 and $\mathbf{4}$, ePTFE minimizes tissue attachment and fibrosis when performing reoperation in glioma patients, lowering the surgery time and complications.

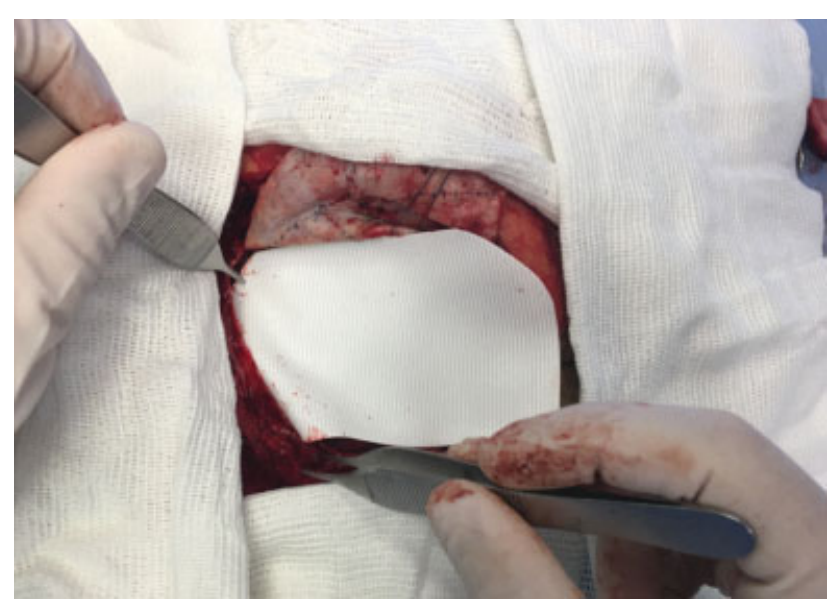

Fig. 1 Expanded polytetrafluoroethylene dura positioning bellow the dura mater of the patient.

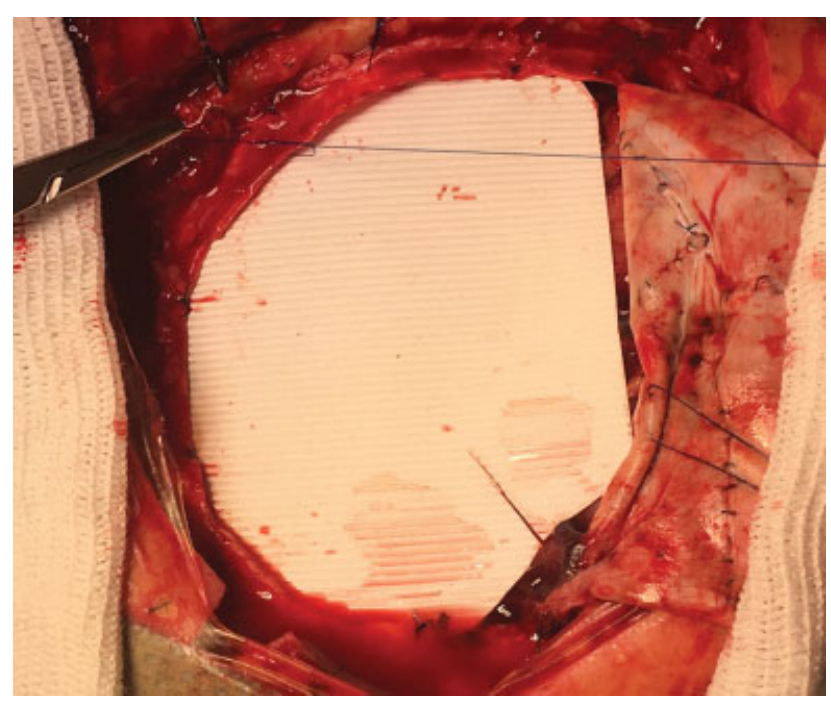

Fig. 2 Expanded polytetrafluoroethylene dura substitute sutured in place with a tension-free technique.

\section{Discussion}

Low-grade glioma is a chronic disease of the brain, and should be treated with a personalized and long-term multistage therapeutic approach. ${ }^{5}$ The importance of surgery and maximal extent of resection (EOR) is well-established in primary LGG management. There is increasing evidence to support maximal EOR for treating recurrent LGG as well, as it may improve progression free survival (PFS) after recurrence and overall survival (OS). ${ }^{1}$ Reoperations of the patients with recurrent LGG have similar risk of neurological complications and sequelae when compared with the initial surgery. ${ }^{6}$

Regarding HGG, Lacroix et al have shown that the EOR improves survival. ${ }^{7}$ Predictive factors of good prognosis after a second surgery include young age, high Karnofsky performance status (KPS) score, gross total resection, and longer time interval between operations. ${ }^{8-11}$ D'Amico et al showed recently a greater total survival in patients $>65$ years old submitted to a second intervention than those submitted to a single surgery. ${ }^{3}$ Moreover, systemic, local, or neurological complication rates were not significantly different between the single-surgery group and the reoperation group in that study. ${ }^{3}$ Chen et al showed similar results and concluded that, in a select group of patients with recurrent grade IV glioblastomas, repeated craniotomy had a significant survival benefit without severely compromising functionality. ${ }^{12}$

The ePTFE dura substitute is indicated for use as prosthesis for the repair of the dura mater during neurosurgery. It has a porosity of $<1 \mu$, which provides excellent conformability and handling while minimizing fibrous tissue ingrowth. This dura substitute serves as an inert, watertight, full thickness dural graft that minimizes tissue attachment between the neural structures and other tissues. ${ }^{13}$ Another advantage is that it becomes translucent after 3 to 4 months in vivo, which allows visualization of the underlying neural structures in reoperations. ${ }^{14}$

Besides avoiding tissue attachment and fibrosis in reoperation, we did not observe cerebrospinal fluid fistula or meningitis in patients with ePTFE dura substitute. This 


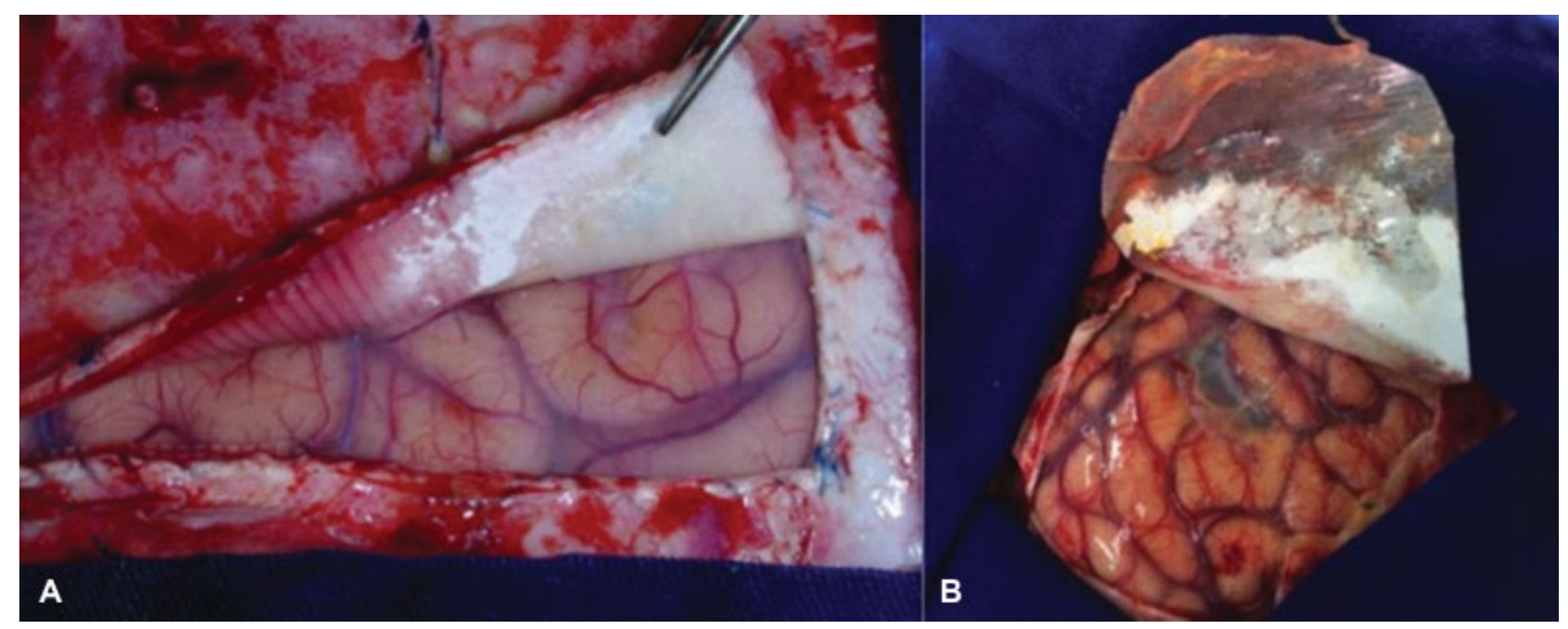

Fig. 3 Brain aspect underneath expanded polytetrafluoroethylene dura.

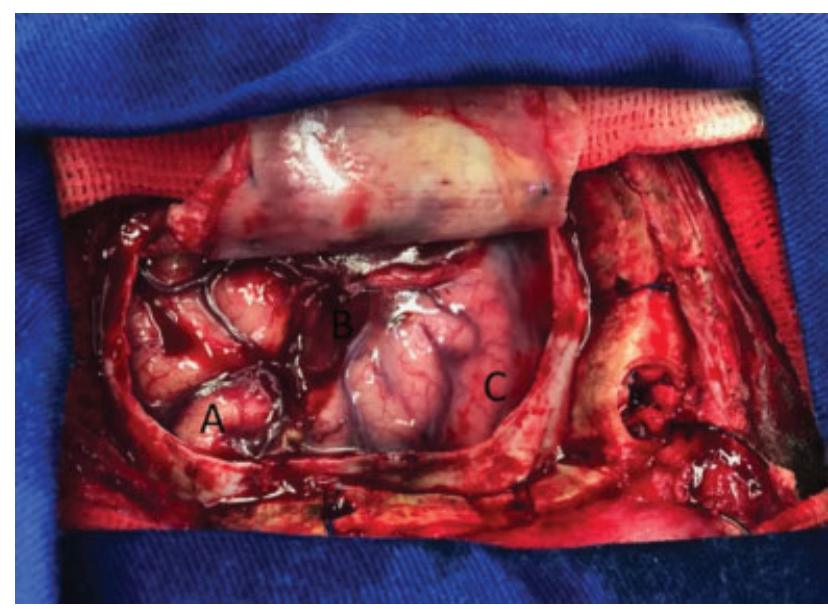

Fig. 4 Comparison of brain surface with and without expanded polytetrafluoroethylene dura substitute in reoperations in a glioblastoma multiforme patient. Tissue attachment and blood vein lesions can be seen in the area with no dura substitute (A), in opposite of preserved anatomy with no fibrosis in tissue covered by expanded polytetrafluoroethylene membrane (C). Between both, previous tumor cavity (B).

membrane has already been shown to be a safe and effective synthetic dura, without the complications observed with other synthetic and biological materials. ${ }^{15-18}$

\section{Conflicts of Interests}

The authors have no conflicts of interests to declare.

\section{References}

1 Uppstrom TJ, Singh R, Hadjigeorgiou GF, Magge R, Ramakrishna R. Repeat surgery for recurrent low-grade gliomas should be standard of care. Clin Neurol Neurosurg 2016;151:18-23

2 Komotar RJ, Starke RM, Connolly ES, Sisti MB. Evaluating the benefit of repeat surgery for recurrent glioblastoma multiforme. Neurosurgery 2010;67(06):N16-N17

3 D'Amico RS, Cloney MB, Sonabend AM, et al. The safety of surgery in elderly patients with primary and recurrent glioblastoma. World Neurosurg 2015;84(04):913-919

4 Park JK, Hodges T, Arko L, et al. Scale to predict survival after surgery for recurrent glioblastoma multiforme. J Clin Oncol 2010; 28(24):3838-3843
5 Duffau H. Taillandier Luc. New individualized strategies in DLGG. In: Diffuse Low-Grade Gliomas in Adults (435-443). Springer, VerlagLondon2013

6 Kaspera W, Majchrzak K, Bobek-Billewicz B, et al. Reoperations of patients with low-grade gliomas in eloquent or near eloquent brain areas. Neurol Neurochir Pol 2013;47(02):116-125

7 Lacroix M, Abi-Said D, Fourney DR, et al. A multivariate analysis of 416 patients with glioblastoma multiforme: prognosis, extent of resection, and survival. J Neurosurg 2001;95 (02):190-198

8 Ammirati M, Galicich JH, Arbit E, Liao Y. Reoperation in the treatment of recurrent intracranial malignant gliomas. Neurosurgery 1987;21(05):607-614

9 Barker FG II, Chang SM, Gutin PH, et al. Survival and functional status after resection of recurrent glioblastoma multiforme. Neurosurgery 1998;42(04):709-720, discussion 720-723

10 Harsh GR IV, Levin VA, Gutin PH, Seager M, Silver P, Wilson CB. Reoperation for recurrent glioblastoma and anaplastic astrocytoma. Neurosurgery 1987;21(05):615-621

11 Dirks P, Bernstein M, Muller PJ, Tucker WS. The value of reoperation for recurrent glioblastoma. Can J Surg 1993;36(03):271-275

12 Chen MW, Morsy AA, Liang S, Ng WH. Re-do Craniotomy for Recurrent Grade IV Glioblastomas: Impact and Outcomes from the National Neuroscience Institute Singapore. World Neurosurg 2016;87:439-445

13 Görtler M, Braun M, Becker I, Roggendorf W, Heiss E, Grote E. Animal experiments with a new dura graft (polytetrafluorethylene)-results. Neurochirurgia (Stuttg) 1991;34(04):103-106

14 Yamagata S, Goto K, Oda Y, Kikuchi H. Clinical experience with expanded polytetrafluoroethylene sheet used as an artificial dura mater. Neurol Med Chir (Tokyo) 1993;33(08):582-585

15 Aliredjo RP, de Vries J, Menovsky T, Grotenhuis JA, Merx J. The use of Gore-Tex membrane for adhesion prevention in tethered spinal cord surgery: technical case reports. Neurosurgery 1999;44(03): 674-677, discussion 677-678

16 Inoue HK, Kobayashi S, Ohbayashi K, Kohga H, Nakamura M. Treatment and prevention of tethered and retethered spinal cord using a Gore-Tex surgical membrane. J Neurosurg 1994;80(04): 689-693

17 Nazzaro JM, Craven DE. Successful treatment of postoperative meningitis due to Haemophilus influenzae without removal of an expanded polytetrafluoroethylene dural graft. Clin Infect Dis 1998;26(02):516-518

18 Tekkök IH. Spontaneous spinal cord herniation: case report and review of the literature. Neurosurgery 2000;46(02):485-491, discussion 491-492 